\title{
Reduction of salinity and sodicity of saline-sodic soils under filed condition in Brazilian semi-arid region
}

\author{
Redução da salinidade e sodicidade de solo salino-sódico em condições de campo na região \\ semiárida brasileira
}

\author{
A. J. da Silva ${ }^{*}$; A. O. Aguiar Netto ${ }^{1}$; A. A. T. Lucas $^{2}$; R. R. de Araújo 2 ; A. F. de \\ Sousa ${ }^{1}$ \\ ${ }^{1}$ Departamento de Engenharia Agronômica, Universidade Federal de Sergipe, 49100-000, São Cristóvão-Sergipe, \\ Brasil \\ ${ }^{2}$ Departamento de Engenharia Agrícola, Universidade Federal de Sergipe, 49100-000, São Cristóvão-Sergipe, Brasil \\ *aironjs@gmail.com
}

(Recebido em 11 de junho de 2020; aceito em 28 de setembro de 2020)

\begin{abstract}
The salinization process in irrigated areas in the semi-arid region of Brazil, constantly cause economic, social, and environmental problems. Therefore, the present research aimed at assessing the effect of different amounts of agricultural gypsum and cow manure associated with an artificial drainage system and salt leaching due to the application of amount of water in a saline-sodic soil under field condition. The experiment was carried out at the irrigated perimeter of Jacaré-Curituba, Poço Redondo, with an experimental design split into plots made of doses of gypsum corresponding to 0,$0 ; 4,300.00$ and $8,600.00 \mathrm{~kg}^{-h^{-1}}$ combined with and without organic matter, cow manure with $25,000.00 \mathrm{~kg} \cdot \mathrm{ha}^{-1}$ and $0.00 \mathrm{~kg} \cdot \mathrm{ha}^{-1}$. Each treatment (six in total) was repeated four times. Thus, 24 plots of $50 \mathrm{~m}^{2}$ were monitored (split plot) with an area of $1.200 \mathrm{~m}^{2}$. All treatments had an artificial drainage system in the center of the plot and the same amount of leach water was then added. The outcomes allowed us to understand that all treatments had the salinity and sodicity soil values reduced at the studied site. Moreover, the treatments with cow manure (source of organic matter) presented the best results, because soil electrical conductivity values $\left(<4 \mathrm{dS} \mathrm{m}^{-1}\right)$ reached the normal level to agricultural yield.

Keywords: irrigation, salinity, sodicity.
\end{abstract}

O processo de salinização em áreas irrigadas do semiárido brasileiro, constantemente, traz consigo problemas econômicos, sociais e ambientais para a região. Portanto, a presente pesquisa teve como objetivo avaliar o efeito de diferentes quantidades de gesso agrícola e esterco bovino associadas a um sistema de drenagem artificial e lixiviação de sal devido à aplicação de quantidade de água em solo salino-sódico em condições de campo. O experimento foi conduzido no perímetro irrigado Jacaré-Curituba, Poço Redondo, com delineamento experimental em parcelas subdivididas compostas de doses de gesso correspondentes a 0,00 ; $4.300,00$ e 8.600,00 kg.ha-1 combinados com presença e ausência de matéria orgânica, esterco bovino com $25.000,00 \mathrm{~kg} \cdot \mathrm{ha}^{-1} \mathrm{e} 0,00 \mathrm{~kg} \cdot \mathrm{ha}^{-1}$. Cada tratamento (seis no total) foi repetido quatro vezes, sendo monitoradas 24 parcelas de $50 \mathrm{~m}^{2}$ (parcelas subdivididas) com área de $1.200 \mathrm{~m}^{2}$. Todos os tratamentos contaram com sistema de drenagem artificial no centro da parcela e foram fornecidos com a mesma quantidade de água de lixiviação. Os resultados permitiram compreender que todos os tratamentos tiveram os valores de salinidade e sodicidade do solo reduzidos no local estudado. Os resultados mostraram também que os tratamentos com esterco bovino (fonte de matéria orgânica) apresentaram os melhores resultados, pois os valores de condutividade elétrica do solo $\left(<4 \mathrm{dS} \mathrm{m}^{-1}\right)$ atingiram níveis normais para a produtividade agrícola.

Palavras-chave: irrigação, salinidade, sodicidade.

\section{INTRODUTION}

The irrigated perimeters in Brazil and the world are the economic and social extreme importance. However, in semi-arid regions, such in the Brazilian Northeast when the irrigation is improperly practiced, salinization and soil sodicity are a threat, as they cause soil degradation, affect agricultural production and compromise the sustainability of region [1].

Irrigated perimeters are essential in the development of Brazilian semi-arid and the public policy have driven the expansion of irrigated areas in recent years [2]. Noteworthy, irrigated areas in Sergipe which started agricultural crops after 2010. Meneses et al. (2016) [3] describes that the Jacaré-Curituba perimeter has 1,870 irrigated hectares spread out in 630 lots with dimensions $090203-1$ 
between 2.5 and 3.0 hectares being the largest irrigated perimeter of Latin America destined to familiar agriculture with 700 benefited families.

Salt affecting areas in the semi-arid of Sergipe have been reported by Aguiar Netto et al. (2007) [4] and Resende et al. (2014) [5] in the California irrigated perimeter at the Jacaré-Curituba, geographic neighborhood of California, saline soils, sodic soils, and information of saline-sodic soils records are found in Lucas et al. (2015) [6]. Soil salinization occurs in all Brazilian northeast states in several perimeters irrigated such as Custódia Irrigated Perimeter- PE [7]; Cachoeira II Irrigated Perimeter- PE [8]; Sumé Irrigated Perimeter - PB [9]; São Gonçalo Irrigated Perimeter PB [10]; Morada Nova, Baixo-Acaraú, Curu-Pentecoste, and Icó-Lima Campos Irrigated Perimeters,- CE [11]; Mandacaru Irrigated Perimeter, BA [12].

Saline and sodic soils are classified by soluble salts and exchangeable sodium present respectively, on horizon and/or layers of soil near the surface with the $\mathrm{CE}$ in the saturated paste superior or equal to $4 \mathrm{dS} \mathrm{m}^{-1}$ and Exchangeable Sodium Percentage (ESP) superior or equal to $15 \%$ [13]. Soil salinity may be of two origins: primary or natural and secondary or anthropic [14, 15, 16]. Secondary salinization resulting from human actions, mainly due to inadequate irrigation management and absence of natural drainage. The main problems in consequence of irrigation are water salinity and salts that rise to the surface due to groundwater rising level $[13,14]$.

Salt-affected soils are found mainly in the arid and semi-arid regions. Salinization caused by irrigation affects 18.4 million ha in LAC, particularly in Argentina, Brazil, Chile, Mexico and Peru The irrigated agricultural area of the northeast region of Brazil is around 500 thousand ha, and 2530 percent is in the process of salinization Irrigation-induced salinization is an important land degradation process that affects crop yield in the Brazilian semi-arid region $[17,18]$.

Salts on soil rightly affect the physiology of plants leading to a nutritional unbalance and toxicity on specific ions as sodium, chlorine, and boron, for instance, the effects of high levels of soluble salts in soil mainly cause an increase in osmotic pressure; consequently, plants are hindered to uptake water from soil $[19,20]$. All physiology damages suffered by the plants are directly due to the low agricultural yield according to Vargas et al. (2018) [21], yield losses are justified by salinization in arid and semi-arid region and can vary depending on the culture from 18 to $43 \%$, which results in great harm to both small and large farmers.

There are two fundamental methods to recover saline areas. One would be washing with a lot of water which can leach it. And two, removing the soluble salts out of the root-zone and chemical ameliorators treatments $[22,23]$. These techniques are considered fundamental for acting in saline and/or sodicity soil reclamation. The ameliorators or chemical correctives are used mainly in salinesodic soils where salts from soil solution have been removed through washing [22]. Calcium sulfate $\left(\mathrm{CaSO}_{4}\right)$ commonly known as gypsum, is one of the main chemical amendments used on the reclamation of saline-sodic soils. Gypsum is normally available and relatively cheap [21, 23].

Organic matter is classified as an auxiliary technique on the process of correcting soil salinity and/or sodicity. Incorporated organic matter acts as a soil structure enhancer, improves soil stability and decreases soil mass, which improves soil porosity and hydraulic conductivity [24].

Studies reported that gypsum associated to organic matter application and water leaching are efficient to recover saline-sodic and sodic soils. However, these techniques are employed in small volumes of soil in labs and greenhouses studies. Therefore, information about their effectiveness under field condition are rare, which can been found in Rasouli et al. (2013) [25] and Birru et al. 2019 [26]. They carried out field experiments on sodic soil and saline sodic soils. Hence, the present study was undertaken to determine the effects of different gypsum and cow manure rates associated to artificial drainage system and salts leaching promoted by a inundation water supply in salinesodic soil under filed condition at the Jacaré-Curituba perimeter located in the Brazilian semi-arid region.

\section{MATERIAL AND METHODS}

Field experiment was carried out in saline-sodic soil at Jacaré-Curituba irrigated perimeter located on Poço Redondo, county, Sergipe State, Northeast of Brazil, semi-arid region (Figure 1). 
The choice of area was made based on soil collection in six lots that showed signs of salinization and flat topography.

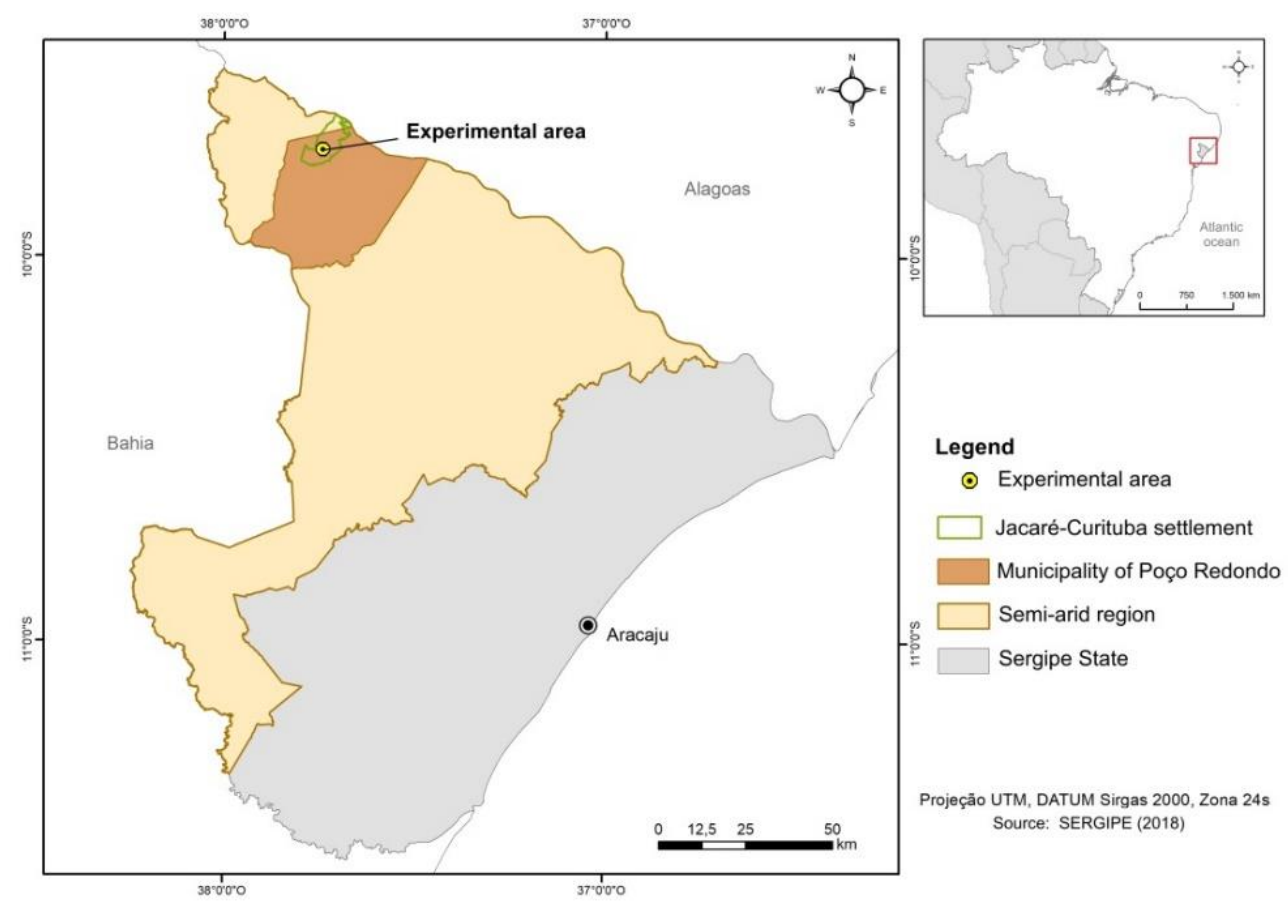

Figure 1: Experimental site location in Sergipe state, northeast of Brazil.

Once the lot was defined the lot a trench was dug, then the soil profile morphology was done (Figure 2) and soil samples to chemical and granulometric analysis were collected, which classified the soil as Salic Sodic Haplic Vertisol [27]. Vertisol are soils with plastic consistency and very sticky due to expansive clay and clay minerals, they show high calcium and magnesium content and can occur from humid climate to dry region like the Brazilian semi-arid [27].

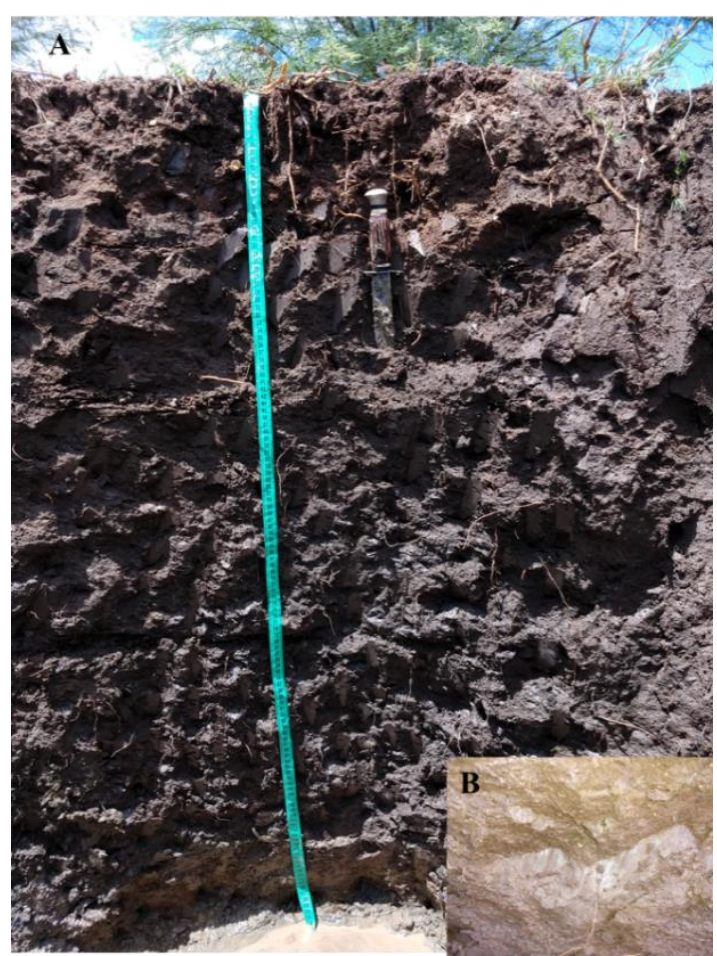

Figure 2: Soil profile (A) and detail of slickensides (B). 
A composed soil sample was taken from an area of 1,200 $\mathrm{m}^{2}$ (area of experiment) at 00.0-0.2 $\mathrm{m}$ depth. The chemical characteristics of samples collected from the research sites are shown in Table 1. As well as saline-sodic soils, the medium salinity parameters values classified the experimental site soil as saline-sodic. In other words, high salinity, EC> $4 \mathrm{dS} \mathrm{m}^{-1}$ and ESP bigger than 15\% [27].

\begin{tabular}{ccc}
\hline Test & Result & Unit \\
\hline pH in Water & 7.32 & -- \\
Calcium + Magnesium & 38.28 & $\mathrm{cmol}_{\mathrm{c}} \mathrm{dm}^{-3}$ \\
Calcium & 22.40 & $\mathrm{cmol}_{\mathrm{c}} \mathrm{dm}^{-3}$ \\
Aluminium & 0.00 & $\mathrm{cmol}_{\mathrm{c}} \mathrm{dm}^{-3}$ \\
Sodium & $1,702.00$ & $\mathrm{mg} \mathrm{dm}^{-3}$ \\
Potassium & 230.87 & $\mathrm{mg} \mathrm{dm}^{-3}$ \\
Phophorus & 28.25 & $\mathrm{mg} \mathrm{dm}^{-3}$ \\
pH da Pasta & 7.14 & -- \\
Organic Matter & 28.07 & $\mathrm{~g} \mathrm{dm}^{-3}$ \\
Magnesium & 15.88 & $\mathrm{cmol}_{\mathrm{c}} \mathrm{dm}^{-3}$ \\
Sodium & 7.40 & $\mathrm{cmol}_{\mathrm{c}} \mathrm{dm}^{-3}$ \\
Potassium & 0.59 & $\mathrm{cmol}_{\mathrm{c}} \mathrm{dm}^{-3}$ \\
Hydrogen + Aluminium & 0.02 & $\mathrm{cmol}_{\mathrm{c}} \mathrm{dm}^{-3}$ \\
SB - Sum of Exchangeable Bases & 46.27 & $\mathrm{cmol}_{\mathrm{c}} \mathrm{dm}^{-3}$ \\
CEC potential & 46.29 & $\mathrm{cmol}_{\mathrm{c}} \mathrm{dm}^{-3}$ \\
ESP & 15.99 & $\%$ \\
V - Base Saturation Index & 99.96 & $\%$ \\
Electrical Conductivity (Soil) & 20.82 & $\mathrm{dS} \mathrm{m}^{-1} \mathrm{to}_{2}^{\circ}$ \\
Soil Classification as to salinity/sodicity & Saline-Sódic & -- \\
Bulk Density (Bd) & 1.36 & $\mathrm{Kg} \mathrm{dm}^{-3}$ \\
Particle Density (Dp) & 2.76 & $\mathrm{Kg} \mathrm{dm}^{-3}$ \\
Total Porosity (Pt) & 50.56 & $\%$ \\
Sand & 303.1 & $\mathrm{~g} \mathrm{~kg}^{-1}$ \\
Silt & 558.3 & $\mathrm{~g} \mathrm{~kg}^{-1}$ \\
Clay & 138.6 & $\mathrm{~g} \mathrm{~kg}^{-1}$ \\
Textural Classification & Franco-Silty & -- \\
\hline
\end{tabular}

At the site of the experiment, harrowing and plowing were carried out to incorporate agricultural gypsum and cow manure. The research design was composed by tree rates of gypsum according to $0 \%$ (control), $50 \%$ and $100 \%$ of gypsum requirement (GR) with the objective to decrease ESP to $8 \%$ at the $0.0-0.2 \mathrm{~m}$ depth, regarding that rates were equivalent to $0.00 ; 4,300.00$ and $8,600.00$ $\mathrm{kg} \cdot \mathrm{ha}^{-1}$ of gypsum and two organic matter rates, with and without organic matter, corresponding to 0.00 and $25,000.00 \mathrm{~kg}$.ha ${ }^{-1}$ of cow manure, where cow manure rates came from a previous study in laboratory. Each treatment was replicated four times. Thus 24 plots of $50 \mathrm{~m}^{2}$ were monitored (split plot) with an area of $1.200 \mathrm{~m}^{2}$. All treatments had an artificial drainage system in the center of the plot and were supplied with the same quantity of leaching water (Figure 3). 


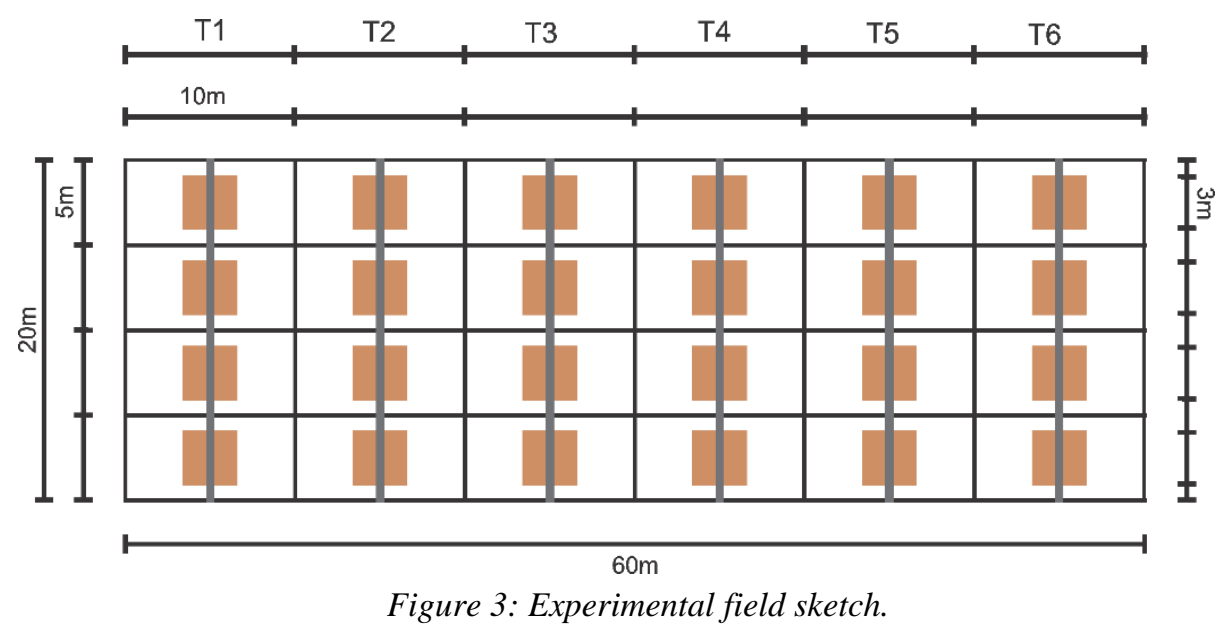
[28]:

The quantity of gypsum required for reclamation was estimated using the following equation

$$
G R=\frac{\left(\left(E S P_{i}-E S P_{f}\right) \times C E C_{\text {potential }} \times E W \times h \times B d\right)}{100}
$$

where, $\mathrm{GR}=$ gypsum required $\left(\mathrm{kg} \cdot \mathrm{ha}^{-1}\right) ; \mathrm{ESP}_{\mathrm{i}}=$ Initial Exchangeable Sodium Percentage (\%); $\mathrm{ESP}_{\mathrm{f}}=$ Final Exchangeable Sodium Percentage (\%); $\mathrm{CEC}_{\text {potential }}=$ Cation Exchangeable Capacity $\left(\mathrm{cmol}_{\mathrm{c}} \cdot \mathrm{dm}^{-3}\right)$; Equivalent Weight of calcium sulfate $=86 ; \mathrm{h}=$ recuperation depth $(\mathrm{cm}) ; \mathrm{Bd}$; Bulk density $\left(\mathrm{kg} \cdot \mathrm{dm}^{-3}\right)$.

In order to reduce the initial ESP from $15.99 \%$ to $8 \%$ in $30 \mathrm{~cm}$ soil depth, irrigation water by intermittent flooding was also applied as recommended by Gheyi et al (2016) [29] for soil that has a fine texture and water table close to the surface, as it is the most efficient method. This water corresponded to an excess of water, based on soil saturation used to leach salts through the artificial drainage system. Total water volume supplied fractioned daily through the irrigation system to all treatments was $327 \mathrm{~m}^{3}$, where each plot received 54,4 $\mathrm{m}^{3}$. Irrigation supply started on May (sixth day) and finished on June (eleventh day) 2020. Figure 4 shows the rainfall during the experiment and its contribution in volume was $63 \mathrm{~m}^{3}$ for total area and $10.5 \mathrm{~m}^{3}$ to each plot. Water requirement was calculated from the equation purpose by Hoffman (1980) [30].

$$
\left(\frac{E C_{\text {final }}}{E C_{\text {se }}}\right) \times \frac{W R}{D s}=k
$$

where: $\mathrm{WR}=$ water requirement $(\mathrm{m}) ; \mathrm{Ds}=$ depth soil to reclamation $(\mathrm{m}) ; \mathrm{EC}_{\mathrm{se}}=$ Electrical conductivity saturated paste extract $\left(\mathrm{dS} \cdot \mathrm{m}^{-1}\right) ; \mathrm{EC}_{\text {final }}=$ Electrical conductivity desired after reclamation $\left(\mathrm{dS} . \mathrm{m}^{-1}\right) ; \mathrm{k}=$ constant related with soil structure. 


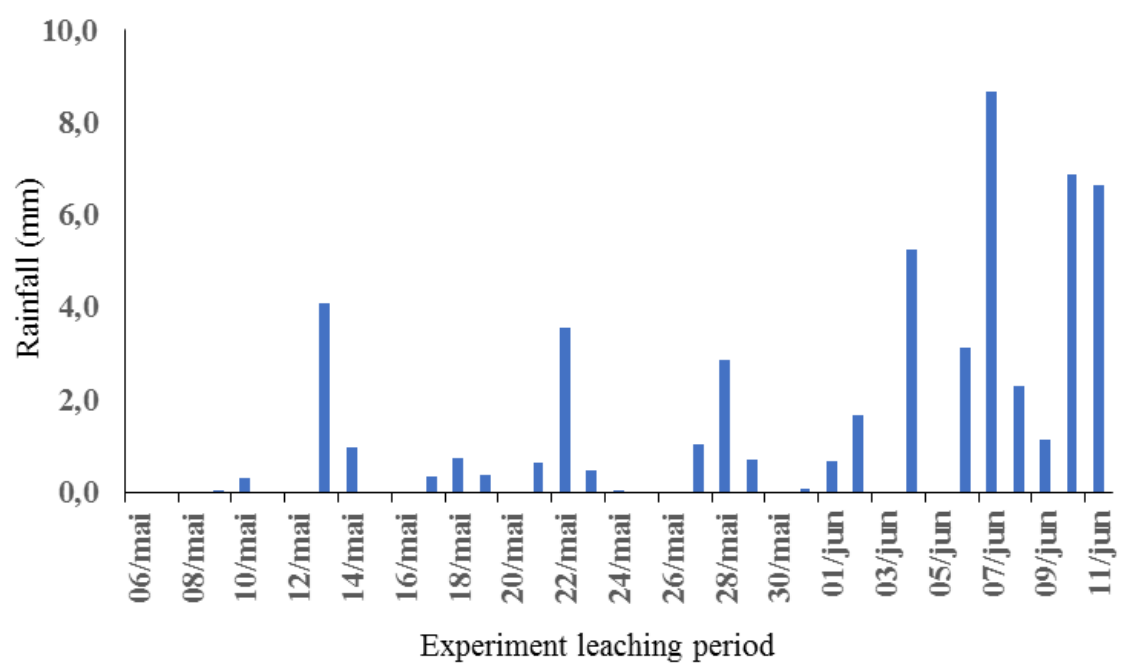

Figure 4: Daily rainfall during the experiment period.

Every plot had, at its center, a subsurface drain located $0.3 \mathrm{~m}$ depth, compose of corrugated flexible and slotted PVC pipe of drainage with $0.1 \mathrm{~m}$ diameter; involved in geotextile blanket lied down about a stone gravel (number zero) layer. Lateral drains to $0.1 \%$ slope connected a secondary drain, glacis 1:1, that outfall in a branch confluent of Jacaré river compound the drainage system of the area during the experiment period at Jacaré-Curituba perimeter.

At the end of the experiment, soil samples were collected in each plot. Five simple samples to make one composed sample at the center of each plot, avoiding border effect of the samples (Figure $3)$.

From these soil samples, chemical characteristics were analyzed according to the methodology described by Gheyi et al. (2016) [31]. The obtained data helped understanding if salinity and sodicity parameters decreased. The soil was then classified considering the final salinity level with initial salinity and sodicity for each treatment. Moreover, physical soil characterization was made; bulk density, particle density and total porosity [32]. The obtained data of the different traits were statistically subjected to the analysis of variance (ANOVA) and Tukey test was applied to 5\% probability with the SISVAR software [33].

\section{RESULTS AND DISCUTION}

Chemical analysis done on the final experiment revealed that electrical conductivity (EC) and exchangeable sodium percentage (ESP) showed differences among treatments (Figures 5 and 6) and all treatments were efficient to decrease these parameters when compared with the initial soil characterization (Table 1). Hafez et al. (2015) [20] found similar results applying gypsum into clay saline-sodic soil when water was added every four days. The biggest EC values for treatments with gypsum can been justified by the not total salt leaching incorporated to soil, also possibly due to high cations and anions concentration affecting calcium solubility. Thus, hindering the ionic change between this cation with sodium. This may take place because Vertisols are naturally rich with calcium and organic matter, thereby gypsum can take increase calcium on soil solution which precipitates as carbonate causing an undesirable effect. 


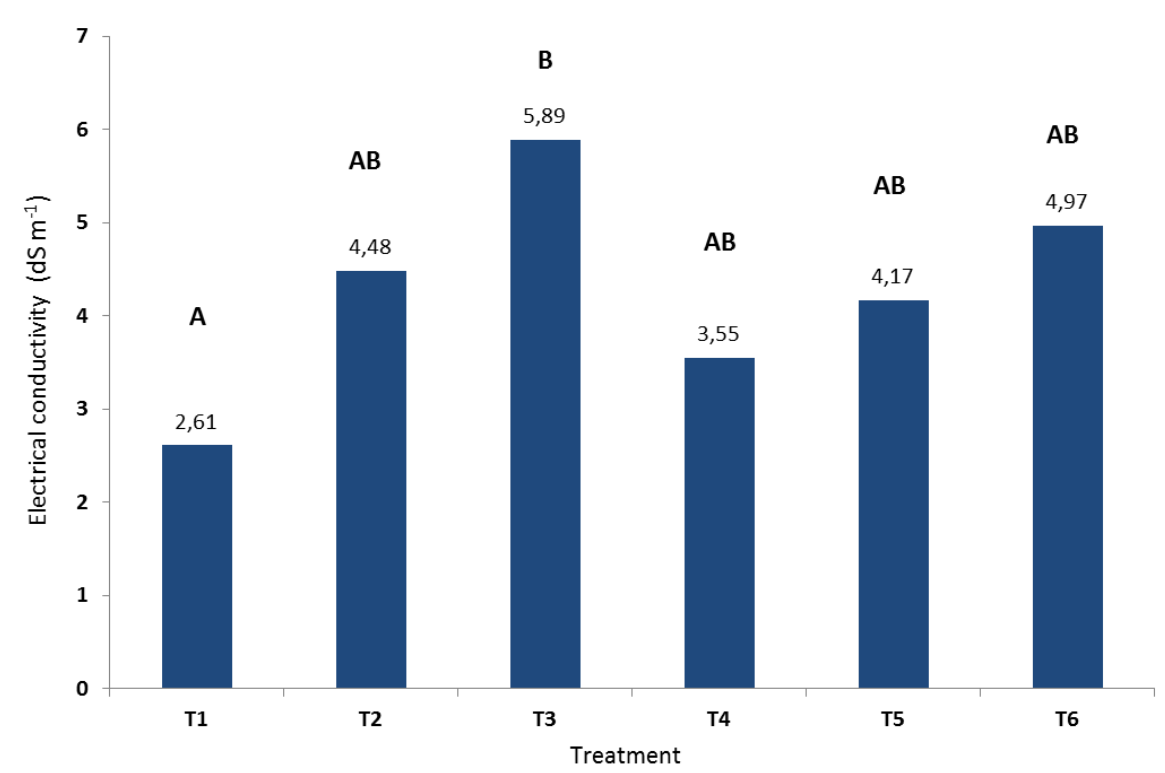

Figure 5: Effect of adopting treatment on soil electrical conductivity after leaching. Average followed of different words of the bars indicate difference among treatments of 5\% by Tukey test. T1 - Cow manure; T2 - Cow manure + 4,300.00 kg of gypsum; T3-Cow manure $+8,600.00 \mathrm{~kg}$ of gypsum, T4 - Control (none cow manure and gypsum); $T 5-4,300.00 \mathrm{~kg}$ of gypsum and T6-8,600.00 kg of gypsum.

Similar outcomes were found in Santos et al. (2019) [34] that studied saline-sodic soil after leaching under field condition, gypsum and gypsum associated with cow manure, rice husk and coconut fiber presented EC superior to $4 \mathrm{dS} \mathrm{m}$-1, whereas the treatments without gypsum EC were inferior to 4 dS m-1. Findings in Rasouli et al. (2013) [25] also showed high EC values when gypsum was applied. Birru et al. (2019) [26] found large EC values varying from $6.79 \mathrm{dS} \mathrm{m}-1$ in 2013 to $13.8 \mathrm{dS} \mathrm{m}-1$ in 2014 during their experiment which was attributed to the capillary movement of cations and anions in the groundwater to the soil surface and it occurred even though tile drainage had been installed at the site.

According to Gomes, Gheyi and Silva (2000) [35] the hypothesis that explains the fact of increasing EC when gypsum is associated, it is related to the solubility because gypsum is a chemical compound of low solubility $\left(2,04 \mathrm{~g} \mathrm{~L}^{-1}\right)$. The authors reported in their research of salinesodic soil reclamation assessing elemental sulfur with gypsum that sulfur was more efficient at the EC, ESP and Sodium Adsorption Ratio decreasing values than gypsum, this can be explained due to low calcium solubility contented in gypsum constrained calcium liberation to soil [36]. Agricultural gypsum $\left(\mathrm{CaSO}_{4} \cdot 2 \mathrm{H}_{2} \mathrm{O}\right)$, is a chemical compound that dissociates in the soil solution and the solubilization of the soluble calcium content increases. This calcium reacts with sodium in the soil exchange complex and displaces it in an exchangeable soluble form. These ion exchanges contribute to the increase in electrical conductivity with the increase in the doses of the produced concealer. Trough leaching the soluble levels of salts and sodium, the salinity is reduced [37]. In this study the water requirement had not been enough to promote dissolution and consequently total gypsum percolating influenced soil solution electrolytic concentration. 


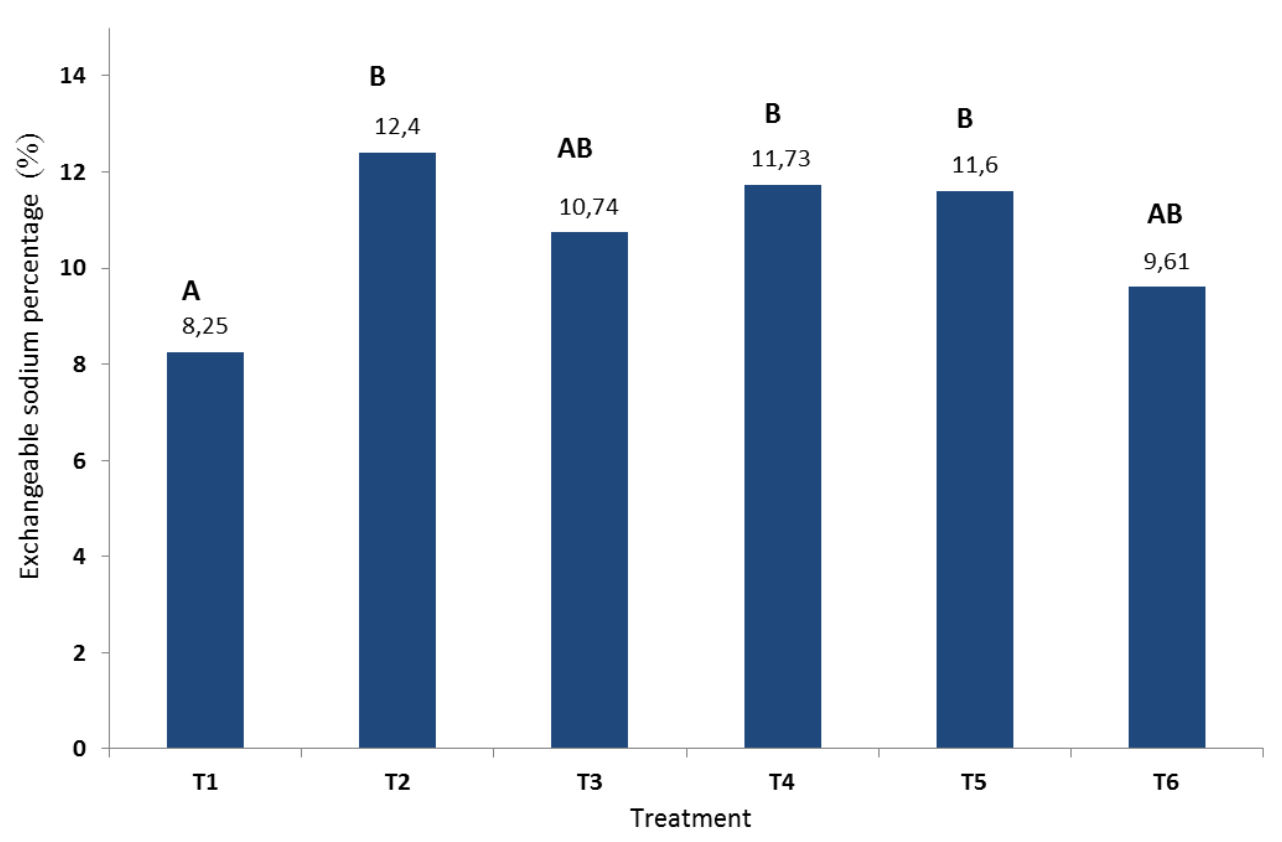

Figure 6: Effect of adopting treatment on soil exchangeable sodium percentage after leaching. Average followed of different words of the bars indicate difference among treatments of $5 \%$ by Tukey test. T1 - Cow manure; T2 - Cow manure + 4,300.00 kg of gypsum; T3 - Cow manure + 8,600.00 kg of gypsum, T4Control (none cow manure and gypsum); T5 - 4,300.00 kg of gypsum and T6 - 8,600.00 kg of gypsum.

The treatments containing cow manure and gypsum absence (T1) and without cow manure (T4) presented the best outcomes to reduce salinity. In both cases, soil was classified as normal related to salinity. The other treatments EC stayed above of $4 \mathrm{dS} \mathrm{m}{ }^{-1}$, probably because the water requirement was not enough as discussed above.

Decreased ESP occurred efficiently for the treatment that received only cow manure followed by treatments with more gypsum rates. Under field condition Sousa (2012) [38] using gypsum and cow manure rates larger than this study observed that these amendments contribute to decrease salinity and sodicity degree, authors also used soil subsoiling as complementary technique.

Cow manure as organic source can contribute to decrease ESP due to $\mathrm{CO}_{2}$ and organic acid liberation during the organic matter decomposition further acting as calcium and magnesium sources in relation to sodium $[33,34]$. The organic acids from organic matter solubilize calcium and this exchange with sodium on soil exchange complex. Regarding that soil has high value of exchangeable calcium (Table 1) it is possible that cow manure had solubilize calcium favoring the ionic exchange process of sodium by calcium in soil exchange complex [39].

The application of gypsum followed by washing with excess of water had a positive effect in decreasing salinity and sodicity providing chemical soil and crop amelioration of different sunrise varieties [40]. Under field condition Hafez et al. (2015) [20] found a significantly higher efficiency in reducing soil sodicity when treated with gypsum and irrigation. Ruiz et al. (2004) [41] working with saline-sodic soil in PVC columns observed that EC and ESP were below $4 \mathrm{dS} \mathrm{m}^{-1}$ and $15 \%$, respectively.

The variables $\mathrm{pH}$ in water, calcium + magnesium, calcium, sodium, phosphorus, organic matter, and Capacity of Exchangeable Cations (CEC) potential presented significative differences among adopted treatments, according to the ANOVA and Tukey test (Table 2). 
Table 2: Chemical attributes of soil influenced by treatments adopted in field experiment.

\begin{tabular}{|c|c|c|c|c|c|c|c|}
\hline \multirow{2}{*}{ Treatments } & pH & $\mathrm{Ca}+\mathrm{Mg}$ & $\mathbf{C a}$ & CEC & $\mathbf{N a}$ & \multirow{2}{*}{$\frac{P}{\mathrm{mg} \mathrm{dm^{-3 }}}$} & \multirow{2}{*}{$\begin{array}{c}\text { OM } \\
\mathrm{g} \mathrm{kg}^{1}\end{array}$} \\
\hline & in $\mathrm{H}_{2} \mathrm{O}$ & \multicolumn{4}{|c|}{-------------cmol dm $^{-3}$} & & \\
\hline T1 & 7.87B & $37.7 \mathrm{~B}$ & 19.1B & 39.7D & $3.27 \mathrm{~B}$ & $21,3 \mathrm{BC}$ & $19.1 \mathrm{AB}$ \\
\hline $\mathbf{T 2}$ & 7.94AB & $37.6 \mathrm{AB}$ & $19.7 \mathrm{AB}$ & $43.9 \mathrm{CB}$ & $5.42 \mathrm{AB}$ & $35.5 \mathrm{AB}$ & $20.4 \mathrm{~A}$ \\
\hline $\mathbf{T 3}$ & $8.01 \mathrm{AB}$ & $31.3 \mathrm{~A}$ & 20.4AB & $47.25 \mathrm{AB}$ & 5.07AB & $43.8 \mathrm{~A}$ & $21.0 \mathrm{~A}$ \\
\hline T4 & $8.31 \mathrm{~B}$ & $37.3 \mathrm{AB}$ & $18.3 \mathrm{~B}$ & 43.1CD & $5.03 \mathrm{AB}$ & $28.8 \mathrm{BC}$ & $19.3 \mathrm{AB}$ \\
\hline T5 & 8.21 AB & $40.0 \mathrm{AB}$ & 20.6AB & 45.9CBA & $5.28 \mathrm{AB}$ & $18.3 \mathrm{C}$ & $16.5 \mathrm{~B}$ \\
\hline T6 & $8.16 \mathrm{AB}$ & $41.9 \mathrm{~A}$ & $23.5 \mathrm{~A}$ & $48,1 \mathrm{~A}$ & $5.68 \mathrm{~A}$ & $27.5 \mathrm{BC}$ & $18.1 \mathrm{AB}$ \\
\hline $\mathrm{CV}(\%)$ & 2.07 & 5.36 & 8.21 & 3.75 & 20.61 & 21.75 & 6.98 \\
\hline
\end{tabular}

Average followed of different words on column for each variable indicate difference to $5 \%$ among treatments by Tukey test. T1 - Cow manure; T2 - Cow manure + 4,300.00 kg of gypsum; T3 - Cow manure $+8,600.00 \mathrm{~kg}$ of gypsum, T4 - Control (none cow manure and gypsum); T5 - 4,300.00 kg of gypsum and T6 - 8,600.00 kg of gypsum.

The sodium content (Table 2) decreased in all treatments when compared with the initial characterization (Table 1). Decreasing was considerable for treatment which only cow manure was used (Table 2). Reduction of exchangeable sodium content followed by reduction of ESP and EC had been observed in field experiment of reclamation of saline-sodic soil that took gypsum and organic sources cow manure [33], the soil changed from saline-sodic condition to none saline after gypsum adoption plus cow manure and gypsum plus rice hulk. Also, the authors also observed that gypsum provided increase of calcium plus magnesium, calcium, and CEC potential soil values. Cow manure promoted $\mathrm{pH}$ reduction and increase of phosphorus and organic matter content of soil.

The largest average obtained for these treatments are related to the addition of gypsum because it is a source of calcium. This ameliorator has the capacity of releasing calcium to soil solution which is a base and it contributes to the increase of calcium and consequently increasing the amount of base and CEC of soil [42].

Gypsum decreased ESP below of $15 \%$ and increased calcium value and salinity. It was also observed that cow manure was beneficial for ESP reduction when applied alone or combined with gypsum [43]. The $\mathrm{pH}$ of saturated paste, magnesium, and potassium presented no difference (Table 3). The same was observed for physical parameters: soil bulk density, particle density and total porosity (Table 3). 
Table 3: chemical and physical of soil not influenced by adopted treatments on field experiment.

\begin{tabular}{|c|c|c|c|c|c|c|}
\hline \multirow{2}{*}{ Treatments } & pH of paste & Mg & $\mathbf{K}$ & Bd & Pd & $\mathbf{P}$ \\
\hline & in $\mathrm{H}_{2} \mathrm{O}$ & Cmol $_{\text {c.dm }}$-3 $^{-3}$ & mg.dm ${ }^{-3}$ & --------kg.dm & -3------ & $\%$ \\
\hline T1 & 7.2 & 16.58 & 278,0 & 1.34 & 2.79 & 51.89 \\
\hline $\mathbf{T} 2$ & 7.83 & 17.95 & 321,3 & 1.32 & 2.75 & 51.93 \\
\hline T3 & 7.81 & 20.98 & 324,8 & 1.32 & 2.76 & 52.25 \\
\hline T4 & 7.97 & 18.98 & 276,0 & 1.34 & 2.77 & 51.74 \\
\hline T5 & 7.94 & 18.38 & 217,0 & 1.33 & 2.78 & 52.03 \\
\hline T6 & 7.93 & 18.40 & 191,5 & 1.34 & 2.78 & 51.82 \\
\hline $\mathrm{CV}(\%)$ & 2.23 & 11.32 & 28,79 & 3.68 & 0.83 & 3.27 \\
\hline
\end{tabular}

The cow manure acts in the positive way improving physical soil conditions. However, there was no significant difference probably justified by short time space between the application of treatments and the soil sample collected. Alves et al. (2007) [44] evaluating application of organic matter observed that there was no alteration of soil physical condition in short time space due to the lack of cementing stable effect of organic substance synthesized by microorganisms at the composition process. Another advantage using manure is the increment of nutrients to soil.

It is possible to observe that the water requirement presented an effectiveness superior to $70 \%$ of salt leaching from soil for all treatments when compared with the start condition of salinity that was of 20,82 dS.m ${ }^{-1}$ (Figure 7). Sodicity also reduced in all treatments keeping the reduction inferior to $50 \%$ for treatments in relation to the initial ESP which was of 15,99\% (Figure 7). 


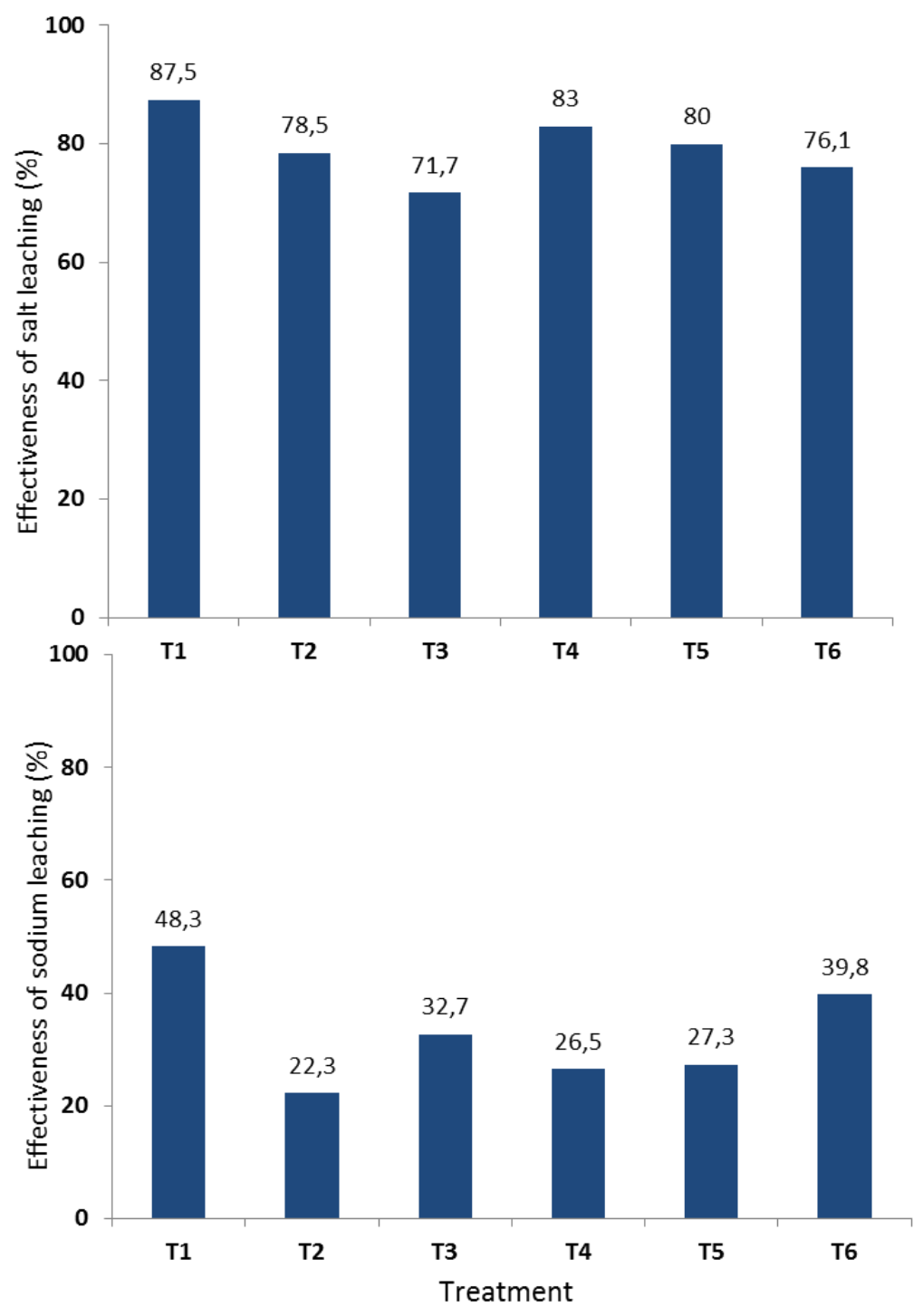

Figure 7: Effectiveness of salt (\%) and sodium leaching (\%). T1 - Cow manure; T2 - Cow manure + 4,300.00 kg of gypsum; T3 - Cow manure +8,600.00 kg of gypsum, T4 - Control (none cow manure and gypsum); T5 - 4,300.00 kg of gypsum and T6 - 8,600.00 $\mathrm{kg}$ of gypsum.

Valdivieso (1984) [45] studying desalinization process of clay soils typical of Nile River delta (Egypt) to determinate parameters to washing with excess of water on reclamation saline soils process verified that water losses occur through deep percolation, evaporation and even superficial runoff. Thus, in this study we may realize that the water requirement in our experiment could have been underestimated and then suggesting that other experiments under field condition assessed different water quantity for purposes of washing with excess of water in saline-sodic soils.

The low effectiveness of ESP decrease from soil when gypsum was applied can be attributed to solubility of this chemical ameliorator which is $2,04 \mathrm{~g} \mathrm{~L}^{-1}$ [25] and can limit calcium release and ionic exchange [35]. Gypsum association with rice hulk decreased ESP in $84 \%$ of the initial value right after washing with excess of water [34], also the same authors observed that treatment with gypsum and gypsum plus organic sources were efficient to reduce this parameter considering the treatment control. In relation to EC washing with excess of water decreased in all treatments, but the lack of gypsum or organic source there was increase of soil ESP. The risk of using only leaching on a saline-sodic soil is to cause soil sodicity, in this case previous study on laboratory are useful for field recommendation. The application of gypsum combined with cow manure was more 
efficient on reducing $\mathrm{pH}$, ESP and sodium adsorption ratio (SAR) of a saline-sodic soil when gypsum is applied alone [46].

More field experiments should be carried out to better understanding of salinity and sodicity behavior and which treatments are in fact effective to reclamation soils, as well as different quantity of water requirements can be tested to leach salts from soil.

\section{CONCLUSION}

The improvement of soil chemical properties in terms of decreasing EC and ESP that caused a significant reduction in soil salinity and sodicity to a level considered as normal for agricultural crops was obtained from treatments with cow manure (source of organic matter). The monitoring of salinity and sodicity at the local experiment in long term should indicate the effectiveness of the best treatment that may be adopted regarding technical and economic aspect for farmers.

\section{ACKNOWLEDGEMENTS}

Project Opará: águas do rio São Francisco, executed by Federal University of Sergipe and Socioenvironmental Canoa de Tolda, sponsored of Petrobras by the Petrobras Socio-environmental Program.

\section{REFERÊNCIAS BIBLIOGRÁFICAS}

1. Aguiar Netto AO, Lima AKVO, Santos TIS, organizadores. Opará. $1^{a}$ ed. Aracaju (SE): Criação Editora; 2019. Chapter 8, Áreas afetadas pela salinização no baixo São Francisco sergipano; p. 147-156.

2. Pontes AGV, Gadelha D, Freitas BMC, Rigotto RM, Ferreira MJM. Os perímetros irrigados como estratégia geopolítica para o desenvolvimento do semiárido e suas implicações à saúde, ao trabalho e ao ambiente. Ciência \& Saúde Coletiva. 2013;18(11):3213-3222, doi: 10.1590/S1413-81232013001100012

3. Meneses TN, Lima IS, Aguiar Netto AO, Pereira FAC, Carvalho CM. Desempenho do sistema de irrigação por microaspersão, no perímetro irrigado Jacaré Curituba-SE. In: Proceedings of the III Inovagri International Meeting; 2015 Jan 1-3; Fortaleza, CE. [place unknown]: Biblioteke Virtual; 2015. p. 17671776, doi: 10.12702/iii.inovagri.2015-a192.

4. Aguiar Netto AO, Gomes CCS, Lins CCV, Barros AC, Campeche LFSM, Blanco FF. Características químicas e salino-sodicidade dos solos do perímetro irrigado Califórnia, SE, Brasil. Ciência Rural. 2007 Non-Dez;37(6):1640-1645, doi: 10.1590/S0103-84782007000600021

5. Resende RS, Amorim JRA, Cruz MAS, Meneses TN. Distribuição espacial e lixiviação natural de sais em solos do perímetro irrigado Califórnia, em Sergipe. Revista Brasileira de Engenharia Agrícola e Ambiental. 2014 Mar; 18(suplemento): S46-S52, doi: 10.1590/1807-1929/agriambi.v18nsupps46-s52

6. Lucas AAT, Santos SJS, Aguiar Netto AO, Santos JA, Lima IS, Farias DBS. Soil salinity in irrigated perimeter Jacaré-Curitiba - SE, Brazil. In: Proceedings of the III Inovagri International Meeting; 2015 Jan 1-3; Fortaleza, CE. [place unknown]: Biblioteke Virtual; 2015. p. 2613-2619, doi:10.12702/iii.inovagri.2015-a281.

7. Freire MBGS, Miranda MFA, Oliveira EEM, Silva LE, Pessoa LGM, Almeida BG. Agrupamento de solos quanto á salinidade no perímetro irrigado de Custódia em função do tempo. Revista Brasileira de Engenharia Agrícola e Ambiental. 2014 Mar;18(suplemento):S86-S91, doi: 10.1590/18071929/agriambi.v18nsupps86-s91

8. Fernandes JG, Freire MBGS, Galvincio JD, Santos PR, Cunha JC. Características físicas e químicas dos solos do perímetro irrigado Cachoeira II em função do tempo. Pesquisa Agropecuária Pernambucana. 2014 Jan-Jun;19(1):33-43, doi:10.12661/pap.2014.006.

9. Carolino JA, Guerra HOC, Araújo WP, Sousa JYB, Almeida ESAB, Barreto HTS. Geoestatística aplicada ao estudo da salinidade do solo, Sumé - Paraíba. Agropecuária Científica no Semiárido. 2017 AbrJun;13(2):72-81, doi 10.30969/acsa.v13i2.669

10. Silva Neto MF, Macedo MLA, Andrade ARS, Freitas JC, Pereira ERR. Análise do perfil agrícola do perímetro irrigado de São Gonçalo-PB. Revista Brasileira de Tecnologia Aplicada nas Ciências Agrárias. 2012 Mai-Ago;5(2):155-172, doi: 10.5777/PAeT.V5.N2.12.

11. Cunha CSM, Hernadez FFF, Silva FN, Escobar MEO, Magalhães DR, Anjos DC. Relação entre solos afetados por sais e concentração de metais pesados em quatro perímetros irrigados no Ceará. Revista 
Brasileira de Engenharia Agrícola e Ambiental. 2014 Mar;18(suplemento):S80-S85, doi: 10.1590/18071929/agriambi.v18nsupps80-s85.

12. Sousa LT, Rodrigues Netto A. Estudo da diversidade de solos e a sua relação com a ocorrência de áreas salinizadas no perímetro irrigado Mandacaru, Juazeiro-BA. In: Proceedings of the XXXIV Congresso Brasileiro de Ciência do solo; 2013 Jul 28-Ago 2; Florianópolis, SC. [place unknown]: [publisher unknown]; 2013. p. 1-3.

13. Gheyi HR, Dias NS, Lacerda CF, Gomes Filho E, editors. Manejo da salinidade na agricultura: estudos básicos e aplicados. $2^{\mathrm{a}}$ ed. Fortaleza (CE): INCTSal; 2016. Capther 2, Origem e classificação dos solos afetados por sais; p. 9-16.

14. Iezzi PBT. Testes de aplicabilidade de sonda de eletrorresistividade na avaliação de salinização secundária de solos [dissertação]. São Paulo (SP): Universidade de São Paulo; 2008. 124 p.

15. FAO. The state of the world's land and water resources for food and agriculture: managing systems at risks. London: Food and Agriculture Organization of the United Nations, Rome and Earthscan; 2011. 285 p.

16. Gonçalves MC, Martins JC, Ramos TB. A salinização do solo em Portugal. Causas, extensão e soluções. Revista de Ciências Agrárias. 2015 Out;38(4):574-586, doi: 10.19084/RCA15140

17. Fao and ITPS. Status of the World's Soil Resources (SWSR) - Main report. Rome (Italy): Food and Agriculture Organization of the United Nations and Intergovernmental Technical Panel on Soils; 2015. $607 \mathrm{p}$.

18. Heinze, BCL. A importância da agricultura irrigada para o desenvolvimento da região nordeste do Brasil [monografia]. Brasília (DF): Ecobusiness School/FGV; 2002. 70 p.

19. Dias AS, Nobre RG, Lima GS, Ghayi HR, Pinheiro FWA. Crescimento e produção de algodoeira de fibra colorida cultivado em solo salino-sódico e adubação orgânica. Irriga. 2016 Fev;1(1):260-273, doi: 10.15809/irriga.2016v1n1p260-273

20. Hafez EM, Abou El Hassan WH, Gaafar IA, Seleiman MF. Effect of gypsum application and irrigation intervals on clay saline-sodic soil characterization, rice water use efficiency, growth, and yield. Journal of Agricultural Science. 2015 Nov;7(12):208-219, doi:10.5539/jas.v7n12p208.

21. Vargas R, Pankovoy EI, Balyuk SA, Krasilnikov PV, Hasanhanova GM, editors. Handbook for saline soil management. [place unknown]: Food and Agriculture Organization of the United Nations and Lomonosov Moscow State University; 2018. 132 p.

22. Gheyi HR, Dias NS, Lacerda CF, Gomes Filho E, editors. Manejo da salinidade na agricultura: estudos básicos e aplicados. $2^{\mathrm{a}}$ ed. Fortaleza (CE): INCTSal; 2016. Chapter 28, Recuperação de solos afetados por sais; p. 461-477.

23. Melo RM, Barros MFC, Santos PM, Rolim MM. Correção de solos salino-sódicos pela aplicação de gesso mineral. Revista Brasileira de Engenharia Agrícola e Ambiental. 2008 Jan;12(4):376-380, doi: $10.1590 /$ S1415-43662008000400007.

24. Miranda MFA. Diagnóstico e recuperação de solos afetados por sais em perímetro irrigado do Sertão de Pernambuco [tese]. Recife (PE): Universidade Federal Rural de Pernambuco; 2013. 102 p.

25. Rasouli F, Pouya AK, Karimian N. Wheat yield and physico-chemical properties of a sodic soil from semi-arid area of Iran as affected by applied gypsum. Geoderma. 2013;193(194):246-255, doi: http://dx.doi.org/10.1016/j.geoderma.2012.10.001.

26. Birru GA, Clay, DE, DeSutter, TM , Reese, CL, Kennedy, AC, Clay, SA, Bruggeman, SA, Owen, R.K, Malo, DD. Chemical amendments of dryland saline-sodic soils did not enhance productivity and soil health in fields without effective drainage. Agronomy, Soils, and Environmental Quality. 2019;111(2):496-508, doi:10.2134/agronj2018.04.0296.

27. Santos HG. Jacomine PKT, Anjos LHC, Oliveira VÁ, Lumbreras JF, Coelho MR, Almeida JA, Araíjo Filho JC, Oliveira JB, Cunha TJF. Sistema brasileiro de classificação de solos. Brasília: EMBRAPA; 2018. $356 \mathrm{p}$.

28. Pizarro F. Drenaje agrícola y recuperacion de suelos salinos: Madrid: Editorial Agricola Española; 1985. $521 \mathrm{p}$.

29. Gheyi HR, Dias NS, Lacerda CF, Gomes Filho E, editors. Manejo da salinidade na agricultura: estudos básicos e aplicados. $2^{\mathrm{a}}$ ed. Fortaleza (CE): INCTSal; 2016. Chapter 28, Recuperação de solos afetados por sais; p. 461-477.

30. Hoffman GJ. Leaching requirement for salinity control in agriculture. In: International Symposium on Salt Affected Soils; 1980 Feb; Karnal, India. [place unknown]: [publisher unknown]; 1980. p. 277-283.

31. Gheyi HR, Dias NS, Lacerda CF, Gomes Filho E, editors. Manejo da salinidade na agricultura: estudos básicos e aplicados. $2^{\mathrm{a}}$ ed. Fortaleza (CE): INCTSal; 2016. Chapter 10, Métodos de análises químicas para solos salinos; p. 123-147.

32. Donagema GK, Campos DVB, Calderano SB, Teixeira WG, Viana JHM. Manual de métodos de análise de solo. Rio de Janeiro: EMBRAPA Solos; 2011.230 p. 
33. Ferreira DF. Sisvar: a computer statistical analysis system. Ciência e Agrotecnologia. 2011 NovDez;35(6):1039-1042, doi: 10.1590/S1413-70542011000600001

34. Santos PD, Cavalcante LF, Gheyi HR, Lima GS, Gomes EM, Bezerra FTC. Saline-sodic soil treated with gypsum, organic sources and leaching for successive cultivation of sunflower and rice. Brasileira de Engenharia Agrícola e Ambiental. 2019 Oct;23(12):891-898, doi:10.1590/18071929/agriambi.v23n12p891-898.

35. Gomes EM, Gheyi HR, Silva EFF. Melhorias nas propriedades químicas de um solo salino-sódico e rendimento de arroz, sob diferentes tratamentos. 2000;4(3):355-361, doi: 10.1590/S141543662000000300009.

36. Sá FVS, Brito MEB, Silva LA, Moreira RCL, Paiva EP, Souto LS. Correção de solo salino-sódico com condicionadores e doses de fósforo para cultivo de sorgo sacarino. Revista Brasileira de Irrigação. 2018; Set;12(5):2854-2865, doi: 10.7127/rbai.v12n500838.

37. Leite EM, Cavalcante LF, Diniz AA, dos Santos RV, Alves GS, Cavalcante IHL. Correção da sodicidade de dois solos irrigados em resposta à aplicação de gesso agrícola. Irriga. 2007;12(2):168-176, doi: 10.15809/irriga.2007v012n2p168-176.

38. Sousa CHC. Uso integrado de práticas de manejo na recuperação de um solo salino-sódico cultivado com coqueiro [tese]. Fortaleza (CE): Universidade Federal do Ceará; 2012. 124 p.

39. Novais RF, Alvarez VH, Barros NF, Fontes RL, Cantarutti RB, Neves JCL. Fertilidade do solo. Viçosa (MG): Sociedade Brasileira de Ciência do solo; 2007. Chapter 16, Fertilidade do solo e seu manejo em solos afetados por sais; p. 929-954.

40. Santos PD, Cavalcante LF, Gheyi HR, Rodrigues MR, Oliveira LP. Gesso agrícola e lavagem de um solo salino-sódico na redução da salinidade e sodicidade no crescimento de plantas de girassol. In: Proceedings os the Inovagri International Meeting; 2012; Fortaleza, CE. [place unknown]: [publisher unknown]; 2012. p. $1-5$.

41. Ruiz HA, Sampaio RA, Oliveira M, Venegas VHA. Características químicas de solos salino-sódicos submetidos a parcelamento da lâmina de lixiviação. Pesquisa Agropecuária Brasileira. 2004 Nov;39(11):1119-1126, doi: 10.1590/S0100-204X2004001100010

42. Foloni JSS, Santos DH, Creste JE, Salvador JP. Resposta do feijoeiro e fertilidade do solo em função da altas doses de calcário em interação com a gessagem. Colloquium Agrariae. 2008 Dez;4(2):27-35, doi: 10.5747/ca.2008.v04.n2.a037.

43. Holanda JS, Vitti GC, Salviano AAC, Medeiros JDF, Amorim JRA. Alterações nas propriedades químicas de um solo aluvial salino-sódico decorrentes da subsolagem e do uso de condicionadores. Revista Brasileiro de Ciência do solo. 1998;(22):387-394, doi: 10.1590/S0100-06831998000300003

44. Alves MC, Suzuki LGAS, Suzuki LEAS. Densidade do solo e infiltração de água como indicadores da qualidade física de um Latossolo Vermelho distrófico em recuperação. Revista Brasileira de Ciência do Solo. 2007;(31):617-625, doi: 10.1590/S0100-06832007000400002

45. Valdivieso CR. Recuperação de solos salinos por lavagem no norte do Egito. Pesquisa Agropecuária Brasileira. 1984 Out;19(10):1247-1255.

46. Gonçalo Filho F, Dias NS, Suddarth SRP, Ferrreira JFS, Anderson RG, Fernandes CS, Lira RB, Ferreira Neto M, Cosme CR. Reclaiming tropical saline-sodic soils with gypsum and cow manure. Water. 2020;12(57):1-13, doi:10.3390/w12010057. 